\title{
SRPSKO TRADICIONALNO CRKVENO POJANJE I NJEGOVA UMETNIČKA NADGRADNJA
}

\author{
Nataša Crnjanski ${ }^{\star}$ \\ Akademija umetnosti, Univerzitet u Novom Sadu, Novi Sad, Republika Srbija
}

Počevši od primanja hrišćanstva u 9. veku, pa sve do današnjih dana, muzika je neodvojivi aspekt liturgijske prakse u srpskom narodu. Razvijajući se primarno pod uticajem vizantijskog pojanja, a nakon autokefalnosti Srpske pravoslavne crkve (1219) i pod uticajem grčkog i ruskog liturgijsko-vokalnog stila, otelotvorenog u vidu tzv. karlovačkog pojanja, srpski crkveno-muzički žanr je prošao dug razvojni put. Na tom putu od jednoglasnog do višeglasnog pevanja, to jest od pojanja do višeglasne horske fakture, dva oblika crkvenog muzičkog žanra zadržala su melodijske i estetske komponente svog prvobitnog monofonog izvorišta. Kako crkveni napevi plene svojom jednostavnošću i lepotom, oni su neretko cantus firmus duhovnog opusa vodećih kompozitora sa ovih podneblja. Tako se od polovine 19. veka pronalaze u stvaralaštvu Kornelija Stankovića, Stevana Mokranjca i srpskih modernista (Tajčević, Hristić, Konjović) do savremenih autora (Mulić, Božić, Govedarica) i svedoče o tome da je crkveno-muzički žanr najdugovečniji umetnički žanr srpske muzike, te svako njegovo recentno istraživanje doprinosi bogaćenju srpske muzičko-kulturne baštine.

"Srpsko tradicionalno crkveno pojanje i njegova umetnička nadgradnja: od klasične i romantičarske obrade do savremene kompozitorske horske prakse" ${ }^{\text {"1 }}$ naziv je projekta oko kojeg je okupljen tročlani tim sa Akademije umetnosti, Univerziteta u Novom Sadu: muzikolog i trombonista dr Nemanja Sovtić i teoretičarka muzike dr Nataša Crnjanski, pod rukovodstvom muzikologa i dirigenta dr Bogdana Đakovića. Osnovne aktivnosti projekta koji se sprovodi tokom 2019/2020. godine, usmerene su na evidentiranje notnih izdanja crkvenog narodnog pojanja, a potom na razvrstavanje pojačkih primera prema žanrovsko-kalendarskom principu, kao i prema tipovima napeva (troparski, stihirarski, mali/silabičan, veliki/melizmatičan), a sve u svetlu njihove kompozitorske primene u delima naših kompozitora klasičnog,

Projekat br. 142-451-2653/2019-01 odobren 17. 06. 2019. godine od strane Pokrajinskog sekretarijata za visoko obrazovanje i naučnoistraživačku delatnost.

natasacrnjanski@live.com 
romantičarskog i modernog izraza. Cilj istraživanja jeste dvojak - sa jedne strane tu je tendencija ka ukazivanju na umetničku vrednost primene crkvenih napeva u duhovnom horskom stvaralaštvu, te iz sociološko-istorijske perspektive njegova usmerenost ka široj publici, a sa druge strane - animiranje potencijalnih savremenih kompozitora za obnovu interesovanja ka oblasti koja je, nažalost, nedovoljno poznata. Sa tim u vezi, tokom projekta je planiran niz aktivnosti koji bi prikazao osnovne „kanone“ srpskog crkvenog narodnog pojanja i njihovu vezu sa crkvenom horskom muzikom, kao i upotreba u bogoslužbenoj i koncertnoj praksi. Krunu projekta predstavljaće završni koncert crkvenog hora „Sveti Georgije“ iz Novog Sada, čiji će repertoar obuhvatiti dijahronijski prikaz mogućnosti „rada“ sa crkvenim napevima, uključujući i one kompozicije koje će biti namenski priređene za tu priliku. Prateći deo programa činiće teorijski tekstovi koji će dopuniti zvučne primere i uputiti na dalja „čitanja" u ovoj oblasti. Time će se ne samo potvrditi ideja o crkvenom pojanju kao nepresušnom izvoru stvaralaštva i umetničkog modela za savremene autore i dirigente, već i njegovo neophodno pozicioniranje u neke nove estetske okvire shodno (post)globalnom vremenu u kome živimo.

Datum prijema članka / Paper received on: 8. 3. 2020.

Datum dostavljanja ispravki rukopisa / Manuscript corrections submitted on: 9. 11. 2020.

(c) 2020 Autor. Objavio Artefact (http://www.artf.ni.ac.rs/index.php/casopis-artefact/).

Ovo je članak otvorenog pristupa i distribuira se u skladu sa Creative Commons licencom (http://creativecommons.org/licenses/by/3.0/rs/).

(c) 2020 The Author. Published by Artefact (http://www.artf.ni.ac.rs/index.php/casopis-artefact/). This article is an open access article distributed under the terms and conditions of the Creative Commons Attribution license (http://creativecommons.org/licenses/by/3.0/rs/).

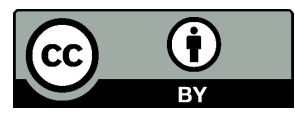

